\title{
研究ノート
}

横浜・川崎に乱ける大気污染の地理学的研究

奥一富 一 成

はじめに エネルギー源として石炭が木材に代わり始めた13世紀後半，イギリスにおい ては早くも石炭を燃焼した際に発生する煙やガスに悩まされていた。一方1895年ペンシル ベニア州で石油のボーリングが成功して以後, エネルギー源として石油は産業や家庭の燃 焼方式を変学，また自動車等の内燃機関の発達に伴って輸送形式も大きく変わるに至っ た。

このようなエネルギー源の翂革は，産業の興隆飞偉大な力となる一方，先の燃焼過程に おいて排出される煙・ガス・煤また悪臭等がもたらす大気污染（Air Pollution）は，人間 の生活環境を触さ公害 (Public Nuisance) として問題視されるに至った。

1930年ベルギーのミューズ渓谷事件をはじめ, ドノラ（アメリカ），ロンドン，ロサン ゼルス等で，またわが国においても横浜，四日市をはじめ各地で大気污染害が多く報告さ れている。 1) 2) 3) 4) 5)

このよらな大気污染関する研究は,これまでもかなり進められてきたが, 従来のもの

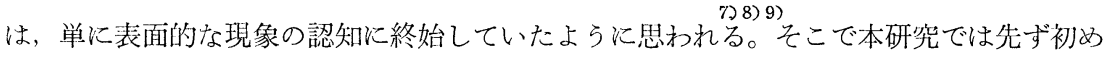
に，獚浜・川崎地方に和ける污染の現状を地域的に分析し，それら污染を引き起こす燃料 等の要因, さらに污染の地域性に種々な点で影響を及ぼす気象条件や地形条件等の自然的 因子について，各々の相関性を明らかにしたい。そうして最後に污染がもたらす種々の影 響のらち，自然環境に対する地域的な影響の分析と，污染の現状との相関性を明らかにし たい。

\section{I 污染の現状とその要因・因子の分析}

\section{1 降下煤塵}

（1）降下煤塵の地域的分布 降下煤塵の夏季扣よび冬季の污染分布をみると第 1 困の ようになる。年間を通じて川崎市田島地区の扇町付近が最污染地域をなし，同地区を中心 に川崎市大師地区, 横浜市鶴見区の臨海地域加川崎市川崎地区, 御幸地区, 中原地区, 
高津地区，横浜市神奈川区の内陸部にかけて活染地域が拡がっていることがわかる。扇町 付近では夏季に 45 ton $\left(\mathrm{km}^{2} /\right.$ 月), 冬季には 35 ton $\left(\mathrm{km}^{2} /\right.$ 月) の等值線が走っており，こ こを中心に夏季，冬季とも 20 ton の等值線まで比較的傾斜のある線を描きながら同心円 状に分布している。

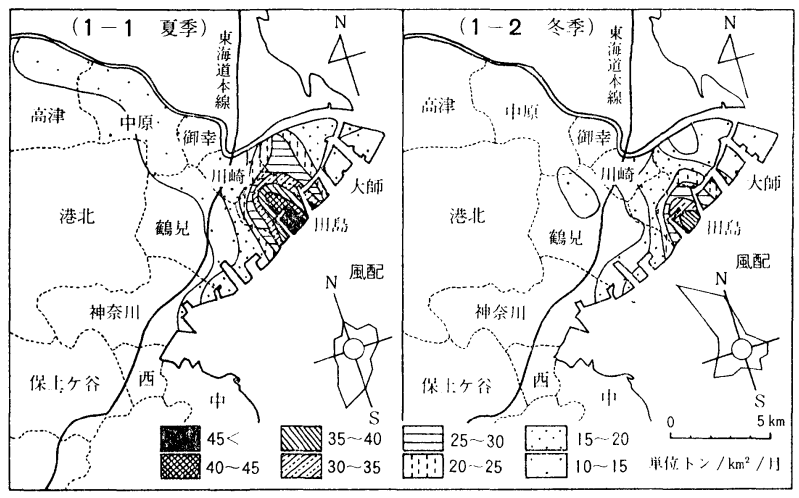

第1図降下煤塵量分布図

横浜市衛生局：大気污染調査と公害処理状況第 4 報 1964 年

污染地域は夏季に田 島地区全域と大師地区 の西部，川崎地区南部 と鶴見区の東部地域 に，そして冬季には扇 町付近を軸に同心円状 に拡がりながらも，比 較的臨海部に沿って分 布している。20 ton 以 上の地域は大師地区の 水江町から桜木町を含 み, 田島地区のほぼ中 央を通り，鶴見区をかすめて分布している。分布地域も夏季に比してほぼ半分である。こ れを 10 ton 以上の地域についてみると，夏季には高津地区の北部をかすめ，中原地区の 大部分と鶴見区の東海道線以南を含み，神奈川区の臨海部に分布して和り，非常に広い地 域に亘って污染を受けている。

冬季は夏季の 15 ton の等值線にほぼ一致し，川崎地区の東海道線以南と鶴見区臨海部 それに同矢向町を中心とする内陸部に分布しているが，污染地域は夏季に比べると極めて 小範囲になる。夏季の污染量が冬季よりも 5 ～10 ton 多い事実は，冬季に污染量を増大さ せている大阪市や北九州市・東京都等に比較して，極めて対象的である。このような季 節的な差異をもたらした原因については後述するが，ふつう大気活染害が冬季に集中して 14) 15) 16)

いることから考えてこれは特筆すべき現象である。

（2）降下煤塵と石炭消費量との関係降下煤塵の要因を知るための指標として，石荻 の消費量（第 2-1 図参照）を取り上げたい。

石炭の年間消費量 100 万 ton 以上 $\left(4 \mathrm{~km}^{2}\right.$ 当たり)を示す地域は, 田島地区の扇町付近か ら少し北部の浜町や鋼管通にかけて分布している。100万 ton の消費地域を中心に，10万 ton の等值線まで注注同心円状に分布しながらも，臨海部にある年間消費量 10 万 ton 以上 
の 5 つの石炭大消費工場の分布地点に沿って, 同心円の輸が比較的平坦に拡がっている。

10万ton の地域までは

污染傾料が急で, その

ため工業地域と非工業

地域の差が判然として いる。

50万 ton の地域は田 島地区の北部を除く全 域と, 鶴見区の東部臨 海地域を包含して打 り, 夏季の 30 ton, 冬 季の 20 ton の煤塵量地 域とほぼ一致してい る。年間 5 万 ton 以上 の地域は, 川崎地区の 南端から鶴見区の東海 道線以南の地域をほぼ 平行して走り, 神奈川

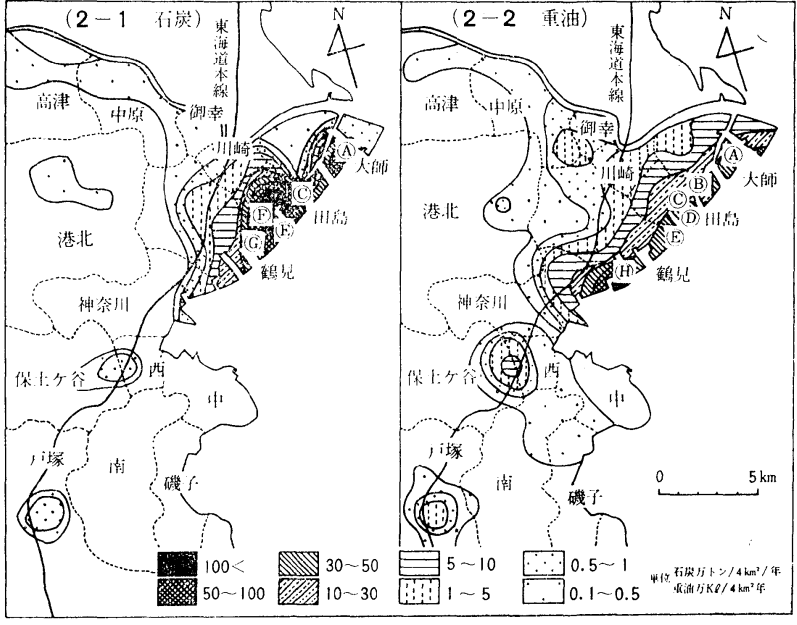

第2図燃料消費量分布図

資料 神奈川県公害課：横浜・川崎市内燃料消費量表 (工場別) 1964年 年間 10 万トン $(\mathrm{kl})$ 以上石炭 (重油) 消費工場
(A) T電力川崎火力発電所 (C) $\mathrm{N}$ 鋼管川崎製鉄所
(E) T電力鶴見火力発電所
(G) $\mathrm{N}$ 鋼管鶴見製鉄所
(B) N鋼管水江製鉄所
(D) M石油川崎製油所
(E) T電力潮田火力発電所
(1) T電力横浜火力発電所

区東部の一部を含む。この 5 万 ton の地域は夏季の 15 ton, 冬季の 10 ton の煤塵量地域に 注ほ致している。1,000 ton の地域は，高津地区の中央部から中原地区の多摩川沿いの 地域，鶴見区の大部分と神奈川区の臨海部を含んで拈り，この地域は夏季の 10 ton の地 域に一致し，各々石炭消費量と降下煤塺量との間には強い相関性が認められる。

（3）降下煤塵に影響を及ぼす風向最初に降下煤塵の地域的分布をみたが，ここでは 何故夏季と冬季で污染量が大きく異なるか，また他都市と違って冬季より复季に污染量が 大きいかについてその原因を明らかにしたい。

冬季に暖房用の然料として石炭を多量に使用するため，石炭消費量は夏季より冬季に多 い。またこの地区に打ける石炭の年間総消費量 (327万 ton) の $47.4 \%$ 占めるT電力の 4 火力発電所 (川崎 - 鶴見・潮田・横浜) の月別の消費量をみても, 夏季の平均が月 7.3 万 ton であるのに対し，冬季では 12.3 万ton を示し圧倒的に多いことがわかる。したがっ て，ここに打いて燃料要因以外にそれら污染物を移動させる因子としての気象条件や，地 形等自然的条件に対する検討が必要となる。 
先ず気象条件との関係であるが，その中でも比較的粒子の大きい降下煤塵は水平方向へ の運搬作用，殊に風向の影響を強く受ける。

第1図から明らかなよらに, 夏季には南から南西寄りの風，すなわち海風が卓越し，最 污染地域の田島地区をはじめとする臨海地域からの污染物が，風によって内陸部にもたら される結果，污染地域を拡げている。㷊塺量 20３0 ton の地域では，その傾向が特に顕 著である。これに対し，冬季には北北西ないし北の風，陸風が卓越し，活染物が海上に流 されるため煤鹿量も少なく, 污染地域も海岸線に平行して分布する。

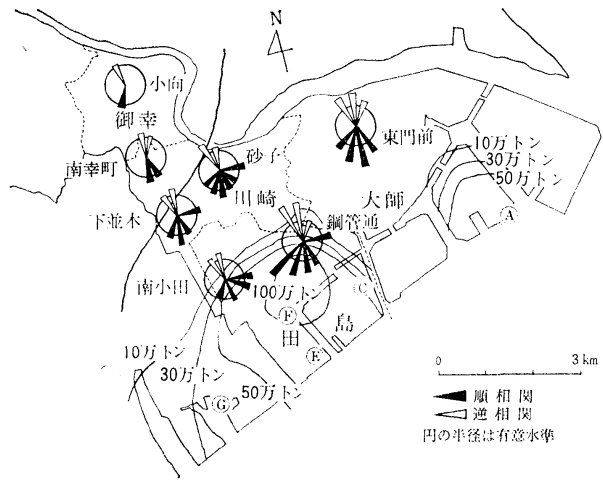

第3 図降下煤塵と風向頻度との相関 凟料 神奈川県宗浜工業地带大気污染防止対策技術 小委員会 : 神奈川県大気污染調査研究報告 第3 報 1960年

年間 10 万トン以上石炭消費工場
(A) T電力川崎火力発電所
(C) $\mathrm{N}$ 鋼管:川崎製鉄所
(E) T電力鶴見火力発電所
(G) $\mathrm{N}$ 鋼管鶴見製鉄所

污染発生源地域と風向との相関を, 川畸市を例にとり，定量的に示すと第 3 戍のようになる。すなわち不炭大消 費地域から風下になる風向のときには 著しい順相関を示している。殊に最大 污染源地域に近い田泉地区の鋼管通, 南小川，大㸝地区の東門前，それに川 崎地区の砂子においてはその傾向が著 しい。一方, 此較的污染源地域加離 れた川崎地区の南幸町や御幸地区の小 向ではそれれど顕著ではない。この ことは風向による影響が近距離におい て顕著で, ほぼ東海道線以南の地域に 限定されることを示している。

次に石炭大消費地域から風上になる

風向，陸風のとさは逆相関を示している。殊に東海道線以南の地域に拈いて顕著で，御幸 地区付近になるとそれほど強い影響は認められない。

このような気象条件は，工場が臨海部に集在していることと相俟って，大気污染害の多 い冬季に污染量を低下させており，地理的に非常に恵をれた条件下にあるといえよう。

気象条件以外の因子として，地形が考元られなければならないが，この地域では高所で も標高 70〜80 $\mathrm{m}$ に過ぎず，接地逆転の発生し易い $200 ３ 00 \mathrm{~m}$ には達しないため，大阪に おケる生駒山のような障害壁にもならず，殆ど問題はない。

（4）降下煤塵の経年推移降下煤塵がここ数年間どのような推移を辿っているかをみ る（第 4-1 図参照）と, 全体的には桨塵量は減少の傾向にあり, 殊に田島地区, 大師地 
区，鶴見区や神奈川区

のような臨海工業地域 においてそれが顕著で ある。その理由として は, 先ず第一に集塵装 置の整備が挙げられ る。すなわち火力発電 ・製鉄・電気炉 - 七メ ント関係の工場におけ る昭和 30 年迄の整備状 況（第 1 表参照）は暴 計 24 基であったもの が，38年には81基とな

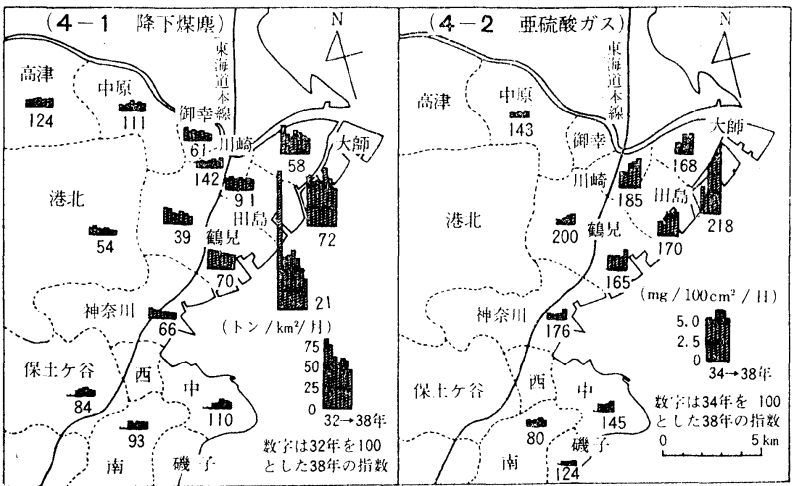

第 4 図污染物経年推移図

資料 川崎市衛生局：川崎市に打ける大気污染資料 1963年 神奈川県京浜工業地带大気污染防止刘策技術小委員会： 神奈川県大気污染調査研究総合報告 1963年. 同小委員会：同研究報告 第 7 報 1964年

り，8年間に 3.4 倍の 伸びを示している。

第 1 表 集魔装置の整啃状沉

\begin{tabular}{|c|c|c|c|c|c|c|c|c|c|c|c|c|}
\hline \multirow[b]{2}{*}{ 年度 } & \multicolumn{2}{|c|}{ 火力発電 } & \multicolumn{2}{|l|}{ 製 } & \multicolumn{2}{|c|}{ 電 気 炉 } & \multicolumn{2}{|c|}{ セメント } & \multicolumn{2}{|c|}{ 累 } & \multicolumn{2}{|c|}{ 訃 } \\
\hline & $\begin{array}{l}\text { 新設 } \\
\text { 件数 }\end{array}$ & $\begin{array}{l}\text { 累設 } \\
\text { 件数 }\end{array}$ & $\begin{array}{l}\text { 新設 } \\
\text { 件数 }\end{array}$ & $\begin{array}{l}\text { 累設 } \\
\text { 件数 }\end{array}$ & $\begin{array}{l}\text { 新設 } \\
\text { 件数 }\end{array}$ & $\begin{array}{l}\text { 累設 } \\
\text { 件数 }\end{array}$ & $\begin{array}{l}\text { 新設 } \\
\text { 件数 }\end{array}$ & $\begin{array}{l}\text { 累設 } \\
\text { 件数 }\end{array}$ & & $\begin{array}{l}\text { 設 } \\
\text { 数 }\end{array}$ & & $\begin{array}{l}\text { 設 } \\
\text { 数 }\end{array}$ \\
\hline $\begin{array}{l}\text { 炤和 } \\
\quad 20 \text { 年以前 }\end{array}$ & 0 & 0 & 11 & 11 & 0 & 0 & 2 & 2 & & 13 & & 13 \\
\hline 21年～29年 & 6 & 6 & 0 & 11 & 0 & 0 & 0 & 2 & & 6 & & 19 \\
\hline 30年 & 3 & 9 & 1 & 12 & 0 & 0 & 1 & 3 & & 5 & & 24 \\
\hline 31年 & 2 & 11 & 0 & 12 & 0 & 0 & 0 & 3 & & 2 & & 26 \\
\hline 32年 & 5 & 16 & 0 & 12 & 0 & 0 & 4 & 7 & & 9 & & 35 \\
\hline 33年 & 1 & 17 & 2 & 14 & 0 & 0 & 1 & 8 & & 4 & & 39 \\
\hline 34年 & 1 & 18 & 0 & 14 & 0 & 0 & 0 & 8 & & 1 & & 40 \\
\hline 35年 & 1 & 19 & 1 & 15 & 1 & 1 & 6 & 14 & & 9 & & 49 \\
\hline 36年 & 2 & 21 & 1 & 16 & 3 & 4 & 8 & 22 & & 14 & & 63 \\
\hline 37年 & 2 & 23 & 3 & 19 & 2 & 6 & 4 & 26 & & 11 & & 74 \\
\hline 38年 & 0 & 23 & 0 & 19 & 3 & 9 & 4 & 30 & & 7 & & 81 \\
\hline
\end{tabular}

資料 神奈川県京浜工業地帯大気污染防止対策技術小委員会 ：神奈川県大気污染調査研究報告 第6 報 1963年 
次に石炭から重油系然料へのエネルギー転換が挙げられる。昭和35年における石炭の消 費量は 353万 ton で，4 年後の同39年には 370 万 ton と 1.05 倍の増加に過ざないのに対 し, 重油は 158 万 $\mathrm{kl}$ から 468 万 $\mathrm{kl}$ と 2.96 倍に増加している。 また燃暁施設等の熱管理 の改善も考它られる。

このよらな集塵装置の整備やエネルギー転換，熱管理の改善が，臨海部の工業地域に降 下煤塵量を減少させている大きな原因となっている。

一方然料消費量の少ない商業地域や住宅地域では，煤塺量自体が低濃度で，あまり開題 でないが，横這いか或いは川崎地区，中原地区，高津地区や中区のように堌大している地 域もある。これは巨額の費用を要する集塵装置の整備能力のない中小企業や，各所に散在

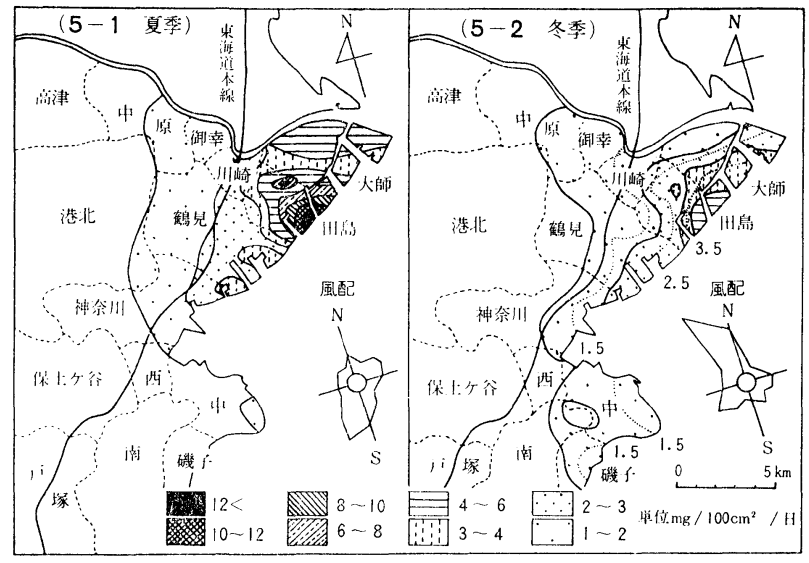

第 5 図 亜硫酸ガス濃度分布図

資料 川崎市衛生局：川崎市における大気污染資料 1963年 横浜市衛生局：大気污染調查と公害処理状況 第 4 報 1964年 する風吕屋，それに家 庭等加らの活染物の排 出が影響していると思 われる。

\section{2 亜硫酸ガス}

（1）亜硫酸ガスの地 域的分布 亜硫酸ガ スの最污染地域は年間 を通じて田島地区の扇 町から水汇町付近にか けて分布し（第 5 図参 照), 降下煤塵の場合と ほぼ同様な傾向を示す。 最高値は夏季·冬季とも扇町で測定され, 夏季は $12.4 \mathrm{mg}\left(\mathrm{SO}_{3} /\right.$ 日 $\left./ 100 \mathrm{~cm}^{2} \mathrm{PbO}_{2}\right)$ と驚異的 な污染值を示している。例えば四日市市の塩浜で $1.05 \mathrm{mg}$, 大阪市の大正区で $3.10 \mathrm{mg}$, 東 京都の江東区で $2.94 \mathrm{mg}$ 等他都市の最污染地域と比較すると，扇町をはじめとする田島地 区や，大師地区の污染濃度が如何に大きいかがよくわかる。勿論測定器設置場所のちがい に依る影響等を無視することは出来ないが，何れにしても大变な污染濃度である。

一方冬季は $4.1 \mathrm{mg}$ と夏季に比べ1/3程度の污染濃度に過ぎないが，他都市の値（四日市 市磯津 $2.87 \mathrm{mg}$ ， 大阪市犬正区 $2.04 \mathrm{mg}$ ，東京都蒲田 $2.34 \mathrm{mg} ）$ と比較すれば決して低い 污染濃度ではない。また夏季の污染濃度が冬季に比べて著しく高いのも降下煤塵量と同様, 特異な現象である。 
夏季は扇町付近の $12 \mathrm{mg}$ の等值線を軸に， $6 \mathrm{mg}$ までは同心円状に分布しているが，田 島地区の浜町付近には $8 \mathrm{mg}$ ，大師地区の未広町から大師河原付近にかけては $4 \mathrm{mg}$ の山 がある。降下煤塵が同心円状に分布しているのに対し，これは異質な傾向を呈している。 そして $3 \mathrm{mg}$ の地域までは污染度の傾斜が非常に密で, それは田島地区, 大師地区それに 川崎地区の南部に限定される。これらの地域から内陸部の商業地域や住宅地域に入ると㱙 染度は極端に低くなり，顕著な地域差を示している。

一方冬季は扇町から水汇町にかけての地域に, $4.0 \mathrm{mg}$ の等值線が走り, 海岸線に平行 して非常に緩やかな污染傾斜をもって内陸部の商業・住宅地域に拡がっていく。そのため商 業・住宅地域では夏季と殆ど污染濃度は変わらない。夏季の $2 \mathrm{mg}$ の地域は東海道線に沿 って神奈川区の東部に延び, 冬季の $1.5 \mathrm{mg}$ の地域とほぼ一致する。中原地区の中部から 鶴見区, 神奈川区の中部に至る $1 \mathrm{mg}$ の線は夏季, 冬季とも殆ど同じ傾向を示し, 住宅地 域における夏季と冬季の污染濃度が一定状態にあることを立証している。

逆に中区付近にあっては夏季上り冬季に活染地域が広く分布している。この分析の詳細 は “気象因子”の所で後述するが，これらの事実は冬季暖房用然料の消費量が堌大するこ と，また降下煤塵と同様，風向等の影響をかなり受けていることを示している。

(2) 亜硫酸ガスと重油消費量との関係亜硫酸ガス発生要因の指標として重油消費量 を取り上げ，地域に対する相関関係をみていきたい。

$4 \mathrm{~km}^{2}$ 当たりの重油消費量(第 $2-2$ 図参照) 100 万 $\mathrm{k} 1$ 以上を示す地区は, 鶴見区の大黒 町付近にある。これは当地域の全重油消費量 468万 $\mathrm{k} 1$ の $17.8 \%$ に当たる 83.4 万1 を消費 する T電力横浜火力発電所があるためである。30万 $\mathrm{k} 1$ 以上の消費地域は大師地区の千鳥町 付近から田島地区，鶴見区，神奈川区宝町付近にかけて臨海部を带状に拡がっている。こ 机は年間 10 万 $\mathrm{k} 1$ 以上を消費する 3 火力発電所 ( T電力一横浜・川崎・鶴見)， 2 製鉄所 ( $\mathrm{N}$ 鋼管一川崎・水江)，1製油所（M石油一川崎）の6工場の分布と全く一致する。 30 万 $\mathrm{kl}$ の等值線と同じく 10 万， 5 万， 1 万 kl といずれも海岸線に沿って带状に分布している。

次に亜硫酸ガス濃度と重油消費量との相関をみると, 冬季には重油消費量 5 万 $\mathrm{kl}$ の等 值線が，大師地区の北部から川崎地区の南部，鶴見区の東海道線以南，それに神奈川区の 東南部臨海地域に走って拈り，2.0 mg の地域とほぼ一致する。 1 万 $\mathrm{kl}$ と $1.5 \mathrm{mg}, 5,000$ $\mathrm{k} 1$ と $1.0 \mathrm{mg}$ の地域も同様であり, 両者の間に相関性のあることが認められる。また鶴見 区大黑町付近と神奈川区宝町付近を除外すれば，他の臨海地域においても同様の相関性が 涊められる。すなわち 30 万 $\mathrm{kl}$ と $4.0 \mathrm{mg}, 10$ 万 $\mathrm{kl}$ と $2.5 \mathrm{mg}$ の地域がそうである。しか し西区と保土ケ谷区の境界付近で 5 万 $\mathrm{k} 1$ ， 戸塚区の吉田町付近に 1 万 $\mathrm{kl}$ の消費地域が局 
所的に存在するにもかかわらず，亜硫酸ガスは殆ど検出されない。勿論西硫酸ガスの測定 網が不十分なため一概には結論は出せないが，前述の分析によって $5,000 \mathrm{kl}$ から 5 万 k1 程度の消費量地域に，亜硫酸ガス漕度との相関性が認められたことは，それら自体が造り 出した相関性というより，寧ろ 30万や 50万 $\mathrm{kl}$ といった大消費地域から派生的に造り出さ れた相関性とみることが出来る。

一方夏季においては大局的には亚硫酸ガス濃度も臨海部から内陸部に移行するにつれ， 低濃度になって抢り，1万 $\mathrm{kl}$ と $2.0 \mathrm{mg} ， 5,000 \mathrm{kl}$ と $1.0 \mathrm{mg}$ の地域にかなり強い相関性 が認められる程度である。

（3）西硫酸ガスに影響を及ぼず大気安定度第 5 図から亜硫酸ガスの夏季・冬季各々 の污染状況と活染濃度, さらに污染分布に地域的な差異引゙あることが明らかとなった。次 に何故かかる傾向を示すに至ったかについての分析を試みることにする。

煙突等から排出される亜硫酸がスの粒子は $0.1 \mu$ 以下という極小粒子が大部尔を占媇て いるため，浮遊地域が気像条件に左右される面が極めて大きい。

気象因子としては，風向の影響が先ず考觉られる。第 $2-2$ 図からもわかるように，冬 季鶴見区大黒町や神奈川区宝町付近から排出された污染物が，卓越する北北西ないし北の 風によって，中区付近に運ばれる。そのため夏季に比して冬季高濃度を現出している。こ のことは夏季についても同様で，卓越する南南西ないし南の風によって污染地域が臨海部 から内陸部にかけて拡がっている。しかし降下煤塵と異なって, 夏季に污染の山が扇町や 浜町，大師河原付近を軸に 3 つ出来ることや，污染地域が田島地区を中心とする陪海工業 地域に極端に偏っていることなどから判断すると，風问や風速の影響をそれほど強く受け ているとは思われない。寧ろ垂直力向への運搬作用として，気温の逆転で示される大気の 安定度による影響が著しい。

第 6 図は亜硫酸ガス濃度と大気安定度（気温近枟度）との相関を求めたものである。そ れに依れば大気が不安定（覑転）なときは污染濃度は低く，反対に安定（迦転）したとき は高いという強い順相関がみられる。

次に覀硫酸ガス濃度と大気安定度の日变化についてみると第 7 図のようになる。亜硫酸 ガス濃度は夏季より冬季に高く，冬季は産業活動の始まる午前 8 時頃から急增し，午前11 时頃に最高濃度を現わす。そうして午後 5 時頃から夜間にかけては低濃度である。一方夏 季は日較差が殆どみられず，夜間に比して日中のほうが $0.1 \mathrm{ppm}$ 高い程度である。

冬季においては，大気は日没頃から午前 9 時頃まで逆転状態にめり，安定している。そ うして太陽の照射が始まるとともに逆転状態は大きく崩れ，日中は順転状態となる。夏季 


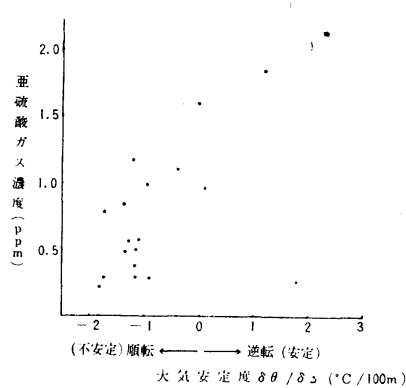

第6 図 悪硫酸ガス濃度と 大気安定度

(1964年12月 4 日〜17日

午前 8:00 10:00 の测定值)

資料 横浜市公害センター：亜硫 酸ガス濃度 $(\mathrm{ppm})$ 及び風速・風向 の測定紽果（自動記録計による） 神奈川県臨㴼地区大父汇染調查協 㼁会：神奈川県臨海地区大気海染 Ir.体骼查報告畫（1964年度冬季）

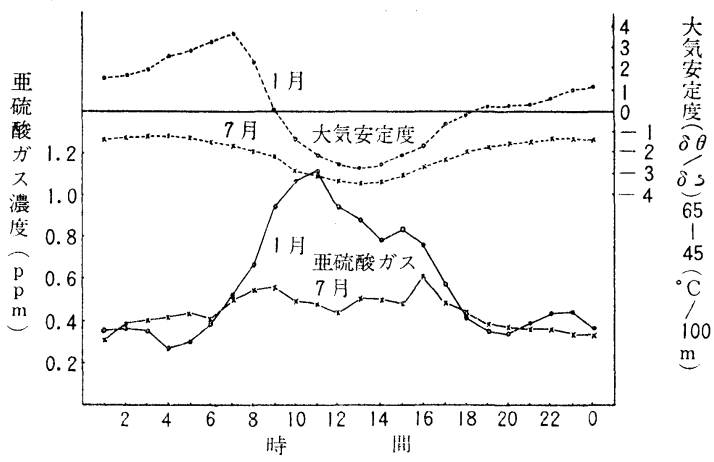

第 7 図 西硫酸ガス濃度と大氛安定度の日变化 (1964年7月と 1965年 1 月の测定值)

凟料 神系川県京浜工業地帯大気污染防止対策技術 小委員会 : 神奈川祡大気污染淍査研究報告 第 7 報 1964年:

には逆転は全くみられないが，当然のことながら夜間 に比して，照射のある日中の汪らが順転度が高い。

开硫酸ガス濃度は逆転が脜れ，順転へのカーブを描くにつれて増大するという顕著な逆 相関を示し，第6図での分析と全く逆の結果が出ている。これは逆転層が形成されている 祭は，層内の上層部に密に浮遊していた活染物が，朔転が崩れるとともに，上層部よりの 大気の乱流によって，上層と下層の機械的乱流が活発に行なわれ，そのため地上付近に活 染物がおり易くなり，高濃度を現出するためである。この祭污染層は下層の接地逆転と， 上䈏の沈降性逆転の二重に存在しており，先ず最初に上層の沈降性逆転がなくなり，その 污染物が下層の接地逆転層内に乱気流によって送り込をれ，高濃度をきたすことになるの である。この現象は Hewson の Fumigation theory として解釈される。これは地形的な 条件からロンドンやロサンゼルスのような盆地や渓谷においてよく観測される現象である が，最近は污染物の增加や Smog 形成の増加等と相俟って，当地のような平坦地に扣いて もしばしばみられる現象になってきた。当地域の Fumigation 現象も㕵硫酸ガス濃度の日 変化をみるのに非常に重要なものである。

（4）覀硫酸ガス濃度の経年推移降下煤塺量は寧ろ減少の傾向にあるのに対し, 亜硫 酸ガスの濃度は総じて増加している（第 4-2 図参照）。殊に污染量の大きい工業地域で の増大が顕著である。例えば昭和34年を 100 とした場合, 同 38年に田荀地区の扇町で 218, 内陸部の工業地域である鶴見区の矢向町付近で 200 と何れも 2 倍の増加を示してい 
る。このよらな現象は，39年までの過去 4 年間におけする重油消費量が 2.96 倍に急増した ことに起因する。殊に大量の重油を消費する工業地域ではその傾向もより顕著である。

一方中原地区や中区, 磯子区などの内陸部の商業, 住宅地域では污染濃度自体も低い が，指数もそれほど大きくは伸びていない。寧ろ南区のように減少している地域もある。 これは内陸部の商業, 住宅地域において然料自体の消費量が少ないらえ, 暖房用等の燃料 として，硫黄分の少ない軽油や燈油を主に使用していることなどによる。しかし降下煤塵 に比して，人体や植物等への影響が大きいことを考觉ると，低濃度であるとはい市，商 業，住宅地域においても大きな問題を孕んでいるのである。

\section{3 排気ガス}

（1）一酸化炭素濃度の分布自動車によって排出される污染物のらち，一酸化炭素に ついて車道を中心とした濃度分布をみると, 先ず車道上の濃度に対して，25m離れた地点 では濃度は1/2に減り,さらに離れるにつれてその值は緩やかに減少し，100mからそれ以 遠では $1 / 5$ 程度の濃度になる。

次に車道上の濃度は交差点で最高值を示し，交差点を離れるに従って急激に減少し，

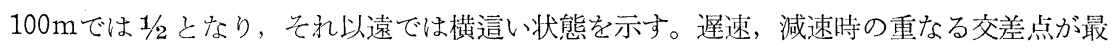
高濃度を現わすのは当然のことであるが，交差点を離れた車道上で一定值を示すのは，自 動車の走行による大気の移動によって, 車道上の一婹化炭素が拡散され, 平均化されるた めと考えられる。

次に交差点付近に和けるそれの垂直濃度分析をみると, 地上 $1 \mathrm{~m}$ 付近で最高值を示し， $3 \mathrm{~m}$ の高さになると1/2Kまで減少する。そうして $3 \mathrm{~m}$ から $10 \mathrm{~m}$ 位までは殆ど変わらず， それ以上高くなると一酸化炭素は殆ど検出されない。

以上，一酸化炭素の水平掞よび垂直濃度分布を分析した結果，降下煤塵や亜硫酸ガスと 異なり, 局地性が大変強く, 交差点の地上 $1 \mathrm{~m}$ 付近を最污染地域として順次污染地域が拡 がっている点が明らかとなった。すなわち交差点付近の民家や商店，をた歩行者等に最覀 の污染現象を現出して括り，早急な対策が望まれる次第である。

（2）一酸化炭素濃度と自動車の交通量, 風速の関係次に一酸化涔素の濃度分胍之, 白動車交通量との相関を第８図からみることにする。

先ず一酸化炭素濃度の日変化をみると, 産業活動の始まる午前 9 時頃に最高濃度を示し ており, 夕刻 $7 〜 8$ 時頃にも小さいながらピークがある。一方污染の要因である交通量は 午前 7 時頃から午後 5 時頃までに多く, 夜間は非常に少ない。

風速が 2 2 m/sec に過ぎない夜間 8 時頃から朝 9 時頃までは, 一酸化炭素濃度と交通 
量とに顕著な順相関がみられるが，6 8 $\mathrm{m} / \mathrm{sec}$ と風速も増し，地上付近の気流が乱れる日 中に括いては相関性は全くみられない。このことは風の弱い気流の安定した状態のとき は, 一酸化炭素濃度と交通 量注相関性が強く認められ るが，風の強い気流の乱れ たときは相関性は認められ ないことを物語っている。 すなわち要因としての交通 量を過小評価するものでは ないが, 一酸化炭素の場合 は風速により強い影響を受 けていると考兄られる。勿 論局地性が非常に強いこと から,車道幅をはじめ,建築

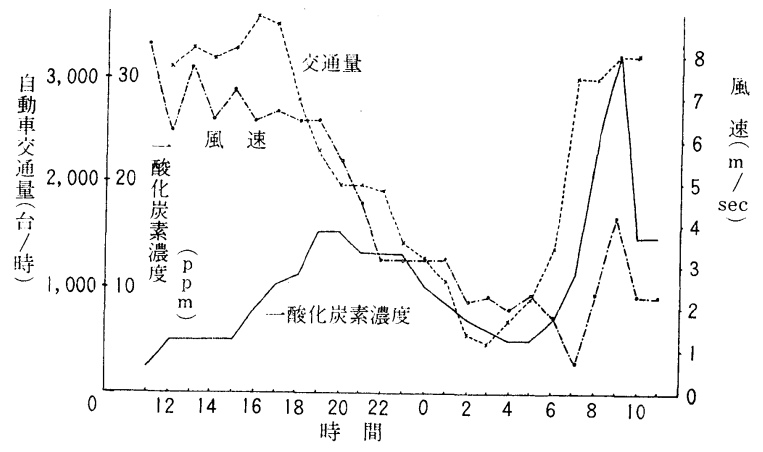

第 8 図一酸化炭素濃度と交通量 （1962年 6 月 21 日 22日の測定値）

資料 神奈川県京浜工業地带大気污染防止対策技術小委員会 : 神奈川県大気污染調查研究報告 第 6 報 1963年

物その他車道周囲の地理的条件によって，分布に大きく影響が生ずることは否定出来ない。 (3) 一酸化炭素濃度と地理的条件第 9 図は地理的条件の異なる 2 地点を選び出し,

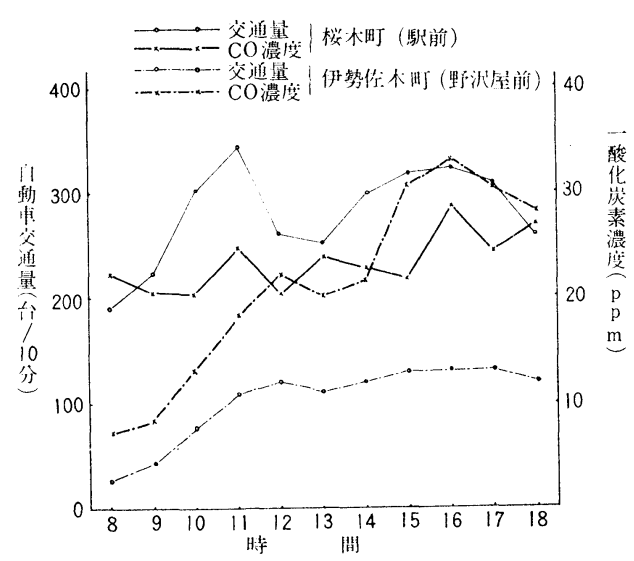

第 9 図 地理的条件の相違による一酸化炭素濃度 （1963年 5 月16日～22日の測定値）

資料 神奈川県京浜工業地带大気污染防止対策技術 小委員会 : 神奈川県大気污染調查研究報告 第 7 報 1964年
地理的条件の相違が一酸化炭素の濃 度分布に，どのような影響を与えて いるかをみよらとしたものである。 桜木町 (中区) は車道幅25mで, 周囲には高層建築物もなく，此較的 開放されているのに対し，伊勢佐木 町 (中区) は車道幅 $8 \mathrm{~m}$ で, 両側に $10 \mathrm{~m}$ 以上の高層建築物が並立して 拉り, 排気ガスの拡散される地域が 極めて限定されている。次に桜木町 の交通量は平均281台/10分であるの に対し，伊勢佐木町は101台/10分と 桜木町の $39.5 \%$ に過ぎない。しかし ながら一酸化炭素濃度は桜木町の平

均 $23.7 \mathrm{ppm}$ の $87.8 \%(20.8 \mathrm{ppm})$ を占めている。そうして夕刻においては伊勢佐木町が桜 
木町を凌ぎ， $32.9 \mathrm{ppm}$ と最高濃度を現わしている。すなわち一酸化炭素の場合，活染 地域が車道上に極めて局地的に現われるため，降下桨塵や覀硫酸ガスと異なり，自動車 交通量や風速にも增して，建築物等の地理的条件に影響される面が極めて大きいのであ る。

\section{II. 大気污染による影響——污染と視程との関係——}

これまで大気污染の現状と要因，因子との相関関係をみてきたが，次にこのような現集 が，周囲に対しどのような影響を与党ているかについて検討を加えることにする。

その影響は広範多岐に亘るが，一応，(1)健康への影響，(2)物質（建築物, 金属, 衣服等） への影響，(3)植物への影響; (4)自然環境（視程の減少，日射量の減少）への影響に大別す ることが出来る。ここでは，(4)自然環境への影響を取り上げて解析していくことにする。

\section{1 自然環境への影響}

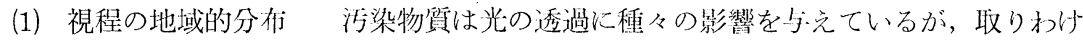
視程の減少への影響が著しい。

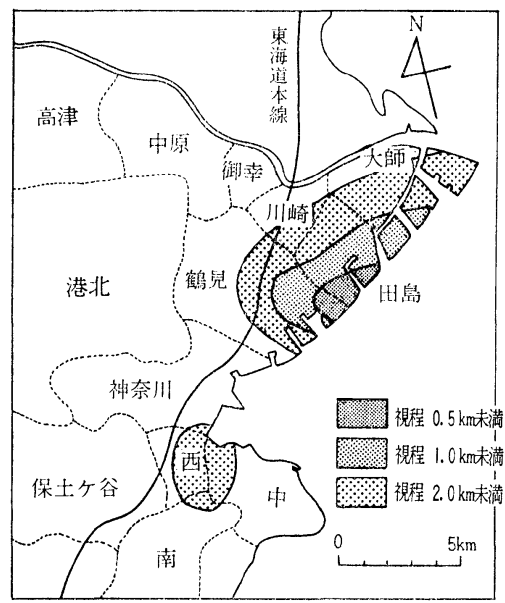

第10図視程分布図

$$
\left(\begin{array}{l}
\text { 1964年 } 2 \text { 月19日 } 3 \text { 月 } 2 \text { 日 } \\
\text { 1964年 } 3 \text { 月 } 10 \text { 日 } ~ 3 \text { 月 } 12 \text { 日 } \\
\text { の全観測平均値 }
\end{array}\right)
$$

資料 神奈川県京浜工業地带大気污染防止対 策技術小委員会 : 神奈川県大気污染調 查研究報告 第 7 報 1964年
そこで視程の地域分布をみると第10図のよ らになる。視程観測地点が僅か19か所に過ぎ ないため, ミクロな分析は不可能であるが， 大体の傾向をつかむことが出来る。

視程 $500 \mathrm{~m}$ 末满の地域は田島地区の南部か ら鶴見区の東部臨海地域にかけて拡がり, $1 \mathrm{~km}$ 未浾の地域は大䢹地区の 南部臨海地域 から田島地区の中央を横断し, 鶴見区の東海 道線の南側を末広町にかけて分布している。 また濃煙霧の指標とされる $2 \mathrm{~km}$ 未満の地域 は大師地区の北部から川崎地区南部，鶴見区 の中部・臨海部を包含しており，また横浜港 を囲んで西区付近にも $2 \mathrm{~km}$ 未満の地域がみ られる。

この視程分们を覀硫酸ガスの冬季の濃度分 布（第 5-2図参照）と比較すると，业硫酸 ガス濃度の中心が田島地区にあり，海岸線に

ほぼ平行して分布しているという点で相関性が認められる。 
次に視程分布を動態的にみる（第11図参照）と,この日（1 日）は午前中,日本海にあっ た気生の谷が夕刻から本邦を覆い，午後 9 封頃に関東地方に達した。風も午前中の東風か

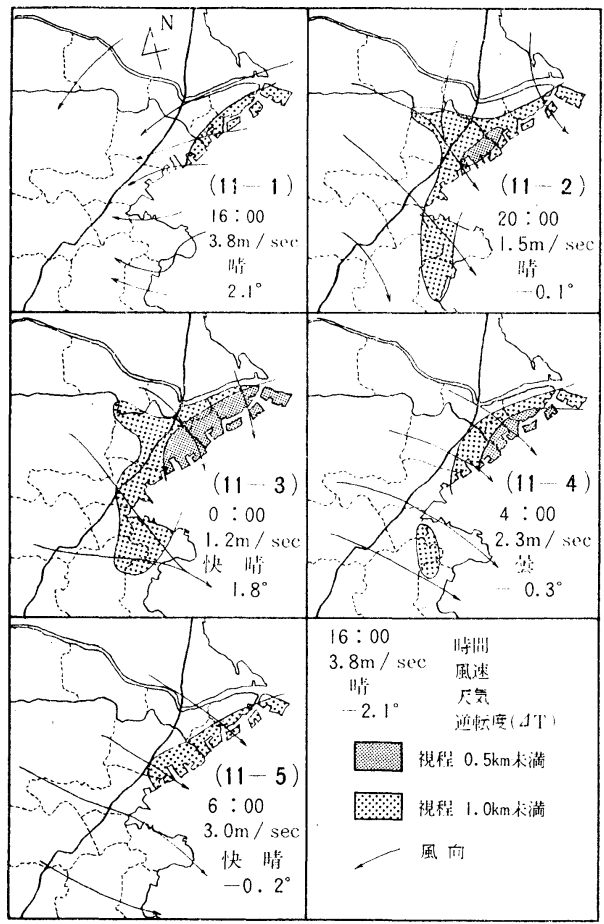

第11図 視 程 分布動態図

(1964年 3 月 1 日 2 日の観测値)

資料 神系川県京浜工業地带大父污染防止対策技術 小委員会 : 神奈川県大気污染調查研究報告 第 7 報 1964年
ら北に移るとともに風速も弱をり， 午後 9 時過ぎには接地逆転が発生し た。2 日午前 0 㸞には接地逆点が最 屯強まり，その後また風も強まって 接地逆転は消隇した。

千後 4 時の視程分芥闵をみると視 程 $1 \mathrm{~km}$ 未满の地域は大師, 田島, 鶴見の海岸線にめり，4m/sec 近い 東風が吹いている。風も $1.5 \mathrm{~m} / \mathrm{sec}$ と弱束り, 東から北に変わって逆転 赝が形成される直前の午後 8 時には, 視程 $500 \mathrm{~m}$ 未満の地域が田島から鶴 見にかけて現われ， $1 \mathrm{~km}$ 未満の地 域も鶴見の内陸部加南区, 磯子 区，中区にかけて拡がりをみせてい る。逆転層が最大になった 2 日午前 0時には $500 \mathrm{~m}$ の地域が大師，田島 の全域と, 鶴見の東海道線以南の地 域に亘って分布している。 $1 \mathrm{~km}$ の 地域も川崎, 神奈川, 西区でな拈も 桩がりをみせている。逆転層が解消

され始め，風も徐々に北から北西に方向を変えた午前 4 時には $500 \mathrm{~m}$ の地域は大師，田島， 鶴見の臨海部の一部に限られ, $1 \mathrm{~km}$ の地域も川崎, 鶴見の東海道線以南の地域に移動し て来た。 $3 \mathrm{~m} / \mathrm{sec}$ と再び風速も増してきた午前 6 時に澡 $500 \mathrm{~m}$ の地域は消減し, 僅かに 1 $\mathrm{km}$ の地域が大師，田島，鶴見の 3 地区の臨海部に分布するのみである。

以上により，気象因子に依る影響は風向に打いてもある程度涩められるが，寧る気温逆 転度や風速に扣いてそれがより顕著であることがわかる。

（2）視程と覀硫酸ガス・気象因子との関係＼cjkstart第12図は濃煙霧と覀硫酸ガス濃度との相 関を求めたものである。 
8 日間の調査期間中，亜硫酸ガス濃度は 6 回に亘って際だったピークを示しており，13 日の午後 4 時を除いてその何れも午前12時前後にピークがある。一方その間に濃煙霧（視 程 $2 \mathrm{~km}$ 以下）は 4 度発生して抢り，やはり13日の午後 4 時前後に発生したものを除い て, 午前 8 時から12時頃に集中している。

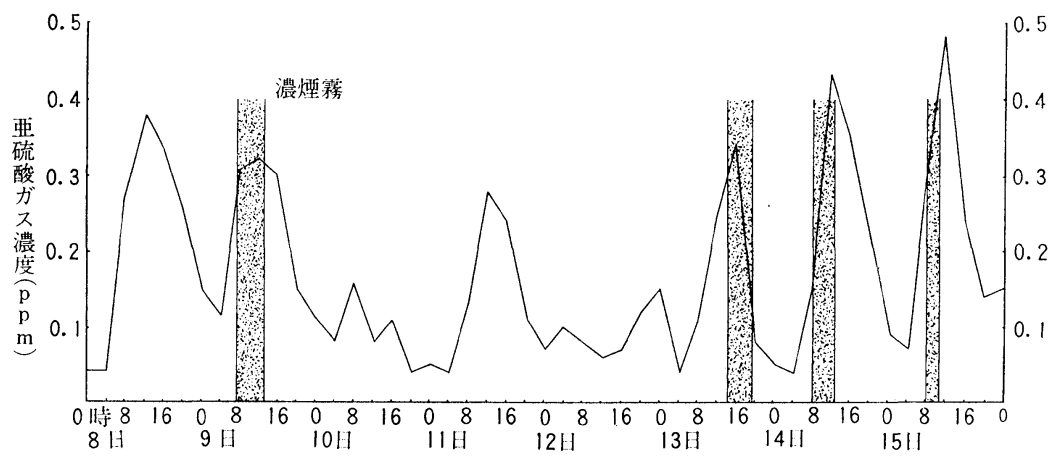

第12図 濃 煙霧と亜 硫酸 ガス 濃 度

（1964年12月 8日〜15日の测定俌＼cjkstart於川崎街生研究所）

資料 神奈川県臨海地区大気污染調查協議会 : 神奈川県臨海地区大気污染立体調查 報告書（1964年度冬季）

4 度発生した濃煙霧のときの亜硫酸ガス濃度は何れも $0.3 \mathrm{ppm}$ を越すピークを示して いる。また Fumigation 現象が起こる午前 8 時頃から濃煙霧が発生し, それにつれて亚 硫酸ガスも濃度を増大させている。濃煙霧が次第に濃くなり, やがて大気が不安定な状態 になる正午頃には濃煙霧は消滅するが, その直後に㝳硫酸ガスはピークを示し, またやが て急激に濃度は低下する。これは濃煙霧に依って地上付近に蓄積された亜硫酸ガスが濃煙 霧の発生している間じゆう, 濃度を高めたためである。

これらのことから濃煙霧と亜硫酸ガスには顕著な相関関係が認められ, 濃煙霧が発生し たときには亜硫酸ガスも高濃度を示すが，しかし逆に亜硫酸ガスが高濃度を現出したから といって, 必ずしも濃煙霧は発生しない。すなわち濃煙霧発生には風速や湿度, 大気安定 度等の気象因子が考慮されなければならない。

先ず風速との相関についてみると, 濃煙霧が発生したときには著しい順相関がみられ, $3 \mathrm{~m} / \mathrm{sec}$ 以上の風速では $1 \mathrm{~m} / \mathrm{sec}$ 增すごとに視程はほぼ $1 \mathrm{~km}$ 良くなっている。 $3 \mathrm{~m} / \mathrm{sec}$ 以下では殆ど相関は認められず，視程に対しては $3 \mathrm{~m} / \mathrm{sec}$ が臨海風速となる。

最後に湿度との関係についてみると, その值が増加するほど視程は減少し, 逆相関を示 している。このことは排出された污染物質が霧などの大気中の水蒸気と凝結核作用を起こ 
し，濃煙霧発生に大きな力となることから十分に察することが出来る。また大気安定度に ついても同様, 視程との間には逆相関がみられる。

むすび大気污染の現状を分析し，それと要因，因子との相関性，および自然環境へ の影響を考察した絬果, 以下のことが明らかとなった。すなわら不炭, 重润等の消費量と 污染濃度とは顕著な相関性を有し，立た污染濃度の形成に気象条件が溞く作用している。 次に排気がスの分布には強い局地性がみられる。

これら污染の現状にもとづいて将来の力向を展望すると, 污染量が減少傾问にある降下 煤麇はともかく，増大傾向を示す亜硫酸ガスに関する対策は絮急を要する。しかし僅か数 社の然料消費工場に低って污染地域が決定されている寒状から, 将来脏硫酸がスの除去が 技術们，経済的に可能となれば，污染濃度を減少させることは比較的容易であると思われ る。これに詨して排気ガスは亚硫酸ガス以上にその対策が緊要で，口サンゼルスで既に㱑 施されているクランクケイス・ブロウバイガス循環装置ならびにテイルパイプからの排胷 ガス除去装置等の排気ガス除去補助装置の整獬が急がれなければならない。また建築物や 道路幅等の地理的条件に依る影響が殊に大きいことから，大交通量本道での本道幅の增大 や立体交差化，平道間囲の建物の低層化等が図られなければならない。

要するに大気污染は，人間に依る経済活動と，気像条件を中心とする自然環境との相関 関係を，総合的に且つ微妙に反映するものである。

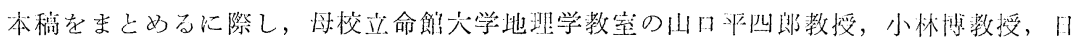
下猚義陆師, さらには京都教育大学水山高幸助教授の御指導に伿らところが六きかった。

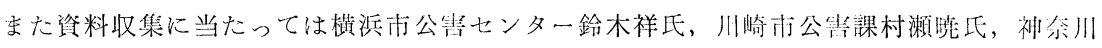
具公㫪課日吉康明氏をはじめ，多くの方々から御協力戴いた。厚く技礼申し上げます。

\section{【注】}

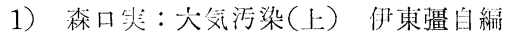

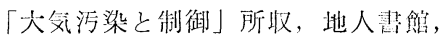
1961, pp. 2 14

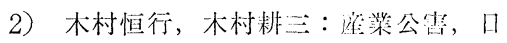
刊工莱新聞社, 1964, p. 6

3）外山敏大, 香川順：スモッグの山の 生活, 獬㹮店, 1965, pp. 33 35, pp. $53 \sim 54$

4）四日市市公羖対策課：四日市访に拉 ける公㫪の概況，四日市市，1964

5）藤森勉：地域の開発と公害一水島不 洲化学コンビナ一トの場合一, 地理10 ๑) 11, 1965, pp. 34〜40
6）主に公采衛生学や父像学を中心とし て研究されている。一例として, 外山 敏夫：大氛污染地区学童の肺換機能匕 ついて, 日本公揫衛生雑誌 8 の 8,19 61。吉田克巳: 学童をめぐる大気汸染 の問題点, 公害 2 の 7,1965 。承見康 二：煤麼に上る京浜工業地帯の大気涯 染第 5 報・符 6 報・第10報, 日本公采

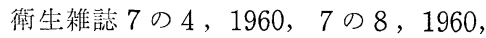
9 の 7，1962 などがある。

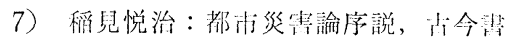
院, 1964

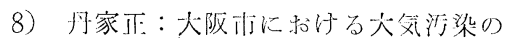


地理的研究，人文地理 15 の 2,1963

9）吉野正敏：ヨーロッパの工業地域之 大気污染，地理10の $10 ， 1965$

10）猿田勝美：横浜市に拈ける大気活染 の先態一大気活染と学望の健康調查一, 公粪 1 の 1,1964

11）大阪市公害対策部：大阪过に打惊る 都市公素の概況，大阪书，1964

12）北九州市衛生局：北九州市大気污染 調查報告，北九州方， 1963

13）東京都首都整備局：東京都内の降下 ばいじん量の調查報告，東尔都，1963

14）森口実：前掲 1)，pp. 2 14

15）木村恒行，木村耕三：前揭 2), p. 6

16）外山利夫，否川順：前掲 3), pp. 33 $\sim 35$

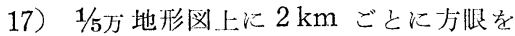
かけ，横浜・川崎方内燃料消費量表 （神奈川県煤煙規制法対象工場の5ち, 回答のあった 232 工場一製造丁業のみ で，ビル暖房等の事業場は含まない。 1964年）から各工場の石炭消費量を地 形戍上に拈として方眼ごとの消費量を 川し，答值線に現わした。

18）神禁川目京浜工業地带大気污染防止: 刘策技術小委員会（以下神条川県技術 委員会と略す）：神奈川紧大父污染調 查研究報告第 3 報, 神奈川県, 1960

19）降下煤塵として測定される中で最も 有効な粒度は20４0 亿である。

20）丹家正：前掲 8), p. 104

21）神杂川罚技術委員会：神条川装大父 污染調査研栄報告第 5 報, 神焚川县, 1962

22）神奈川県公青課：前揭 17）一横浜 · 川崎市内燃料消費量表, 神条川県, 1964

23）一般に以州硫陵ガス羱度が $9 \mathrm{mg}$ に なると鼻で感知出米, $18 \mathrm{mg}$ 程度にな ると急激な刺激を感ずる。しかしこの 数值はあくまで瞬閏的なものであるの
に対し, 当地方の $12.4 \mathrm{mg}$ という数 值は季節の平均优である。ために瞬閏 的な濃度では上記の濃度を遥かに越之 ていると推測される。森口起：前掲1)， p. 38, 佐藤武犬, 奥㳀楥, 高橋裕 :

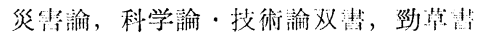
房， 1964, p. 167

24）四日市术公䒠対策課：解掲 4)

25）大阪标公害対策部：前掲 11）

26）東京都都市公盽部：東京都における 都市公量の概沉, 東京都, 1964

27）森口氠：前掍 1)，p. 73

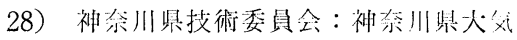
污染調查破究報告第 7 報, 神等川景, 1964, pp. $76 \sim 81$

29）森口央：前掲 1)， p. 50

30）清浦雷作: 公垈人の挑戦, 淇淡补, 1966, pp. 110 112

31）㷊口失：前揭 1), p. 10

32）木村恒行，木村耕：：前掲 2)， p. 71

33）神公川県抄術委買会：前掲 18), p. 87

34）神余川柴技術委只会：㓩掲 18)，p. 88

35） 1965年 3 月に東京電力と中部電力で 硫潢陵化物の除去の咲用化試験に成功 している。東電の場合は建設費が35万 $\mathrm{kW}$ の発電機で 2 億円程度であるが, $\mathrm{SO}_{3}$ (無水硫酸) しか完全除去されず, また回收物の経济性も低い。…方中䉓 の場合は $\mathrm{SO}_{3}, \mathrm{SO}_{2}$ とも完全除去出米,

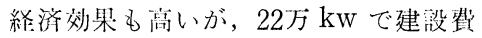
が10億円もかかる久点がある。朝日啋 聞1965年 3 月 24 日付朝刊

36）投上勉：大阪术の自動車排父がス刘 策に関する問題点一ロスアンゼルスの

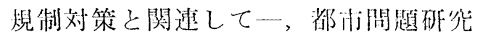
17 の 3 , 1965, pp. $79 \sim 83$

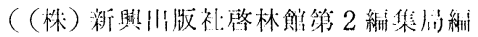
集部) 